\title{
Cytokine actions in growth disorders associated with pediatric chronic inflammatory diseases (Review)
}

\author{
V.E. MacRAE ${ }^{1,2}$, S.C. WONG ${ }^{2}$, C. FARQUHARSON ${ }^{1}$ and S.F. AHMED ${ }^{2}$ \\ ${ }^{1}$ Bone Biology Group, Division of Gene Function and Development, Roslin Institute, Edinburgh; \\ ${ }^{2}$ Bone and Endocrine Research Group, Royal Hospital for Sick Children, Glasgow, UK
}

Received June 29, 2006; Accepted August 28, 2006

\begin{abstract}
Growth disorders are commonly observed in children suffering from chronic inflammatory diseases such as Juvenile Idiopathic Arthritis (JIA) and Inflammatory Bowel Disease (IBD). These disorders range from general growth retardation to local acceleration of growth in the affected limb and are associated with the increased production of proinflammatory cytokines. In this article, we review how cytokines influence child growth by exerting a local effect at the level of the growth plate, and through systemic effects throughout the whole body.
\end{abstract}

\section{Contents}

1. Introduction

2. Growth and bone disorders associated with chronic inflammatory disease

3. Systemic and local control of bone growth

4. Systemic effects of cytokines through the GH/IGF axis

5. Local effects of cytokines on the growth plate through the $\mathrm{GH} / \mathrm{IGF}$ axis

6. Conclusions

\section{Introduction}

Abnormal growth patterns are commonly observed in children suffering from chronic inflammatory diseases such as Juvenile Idiopathic Arthritis (JIA) and Inflammatory Bowel Disease (IBD), both at the onset of the disease and after steroid treatment. Changes in bone development are commonly associated with the growth abnormalities observed in these children. An imbalance of pro-inflammatory cytokines is

Correspondence to: Dr V.E. MacRae, Division of Gene Function and Development, Roslin Institute, Roslin, Midlothian EH25 9PS, UK

E-mail: vicky.macrae@bbsrc.ac.uk

Key words: juvenile idiopathic arthritis, inflammatory bowel disease, growth plate chondrocytes, cytokines, growth failure often seen in children with inflammatory diseases (1-5). The pro-inflammatory cytokines that have been reported to play a major role in JIA and IBD include interleukin-1ß (IL-1B), tumour necrosis factor $\alpha(\mathrm{TNF} \alpha)$ and interleukin-6 (IL-6) (6-10).

Individual cytokines have multiple target cells and multiple actions, which often overlap with other cytokines. Cytokines may act as antagonists to or synergists with another, or may have a combined action altogether disparate to the individual agents. The action of cytokines is exerted via specific highaffinity cell surface receptors resulting in changes in gene expression of the target cell. Receptors of different cytokines share common signal transduction pathways allowing "cross over' effects. Pro-inflammatory cytokines may act individually or in combination to influence child growth through systemic effects and/or a local effect at the level of the growth plate of long bones.

\section{Growth and bone disorders associated with chronic inflammatory disease}

In children suffering from JIA, estimates of significant short stature (final height SDS of <-2) range from $11 \%$ of patients with polyarticular JIA (11) to $41 \%$ of patients with systemic JIA (12). Child growth and skeletal development are reversibly impaired during periods of intensive glucocorticoid therapy (13). However, significant deviation of adult height from mid-parental height has been reported to be present only in children treated for longer than 12 months with systemic steroids (14). In a retrospective study of 24 children with systemic JIA (12), 87\% of patients had a final height less than their target height. Furthermore, no catch-up growth was observed in $30 \%$ of the children following disease remission and the termination of glucocorticoid therapy. These patients were probably shorter at the time of diagnosis and had lower target heights (12).

Pubertal development is compromised in girls with JIA, particularly if they have received glucocorticoid therapy (15). Furthermore, girls with systemic JIA have a later menarche than those with polyarticular or oligoarticular JIA (15).

Children suffering from JIA show a distinctive pattern of growth disturbance; oligoarticular JIA is associated with localised excessive bone growth, whereas general growth retardation is often observed in children with systemic JIA. In the younger child with oligoarticular JIA, increased growth 
in the affected limb occurs, with early fusion of the epiphyses leading to limb shortening in the older child (16). Early treatment of a young child with oligoarticular JIA with intraarticular glucocorticoids may avoid the leg length discrepancy, however this treatment may inhibit the growth of the contralateral leg $(17,18)$.

Growth failure is a major feature of childhood IBD, and is more commonly observed in Crohn's disease (CD) rather than ulcerative colitis. Approximately 10-15\% of children with $\mathrm{CD}$ have severe growth failure (height SDS <-2) at diagnosis $(19,20)$. A prospective multi-centre study showed that approximately $21 \%$ of patients remain $<-2$ SDS after 2 years of follow-up (19).

Pubertal growth represents $15-20 \%$ of adult height, and precedes the fusion of the growth plates (21). Delayed puberty is common in patients with IBD, particularly CD $(22,23)$. In a study of young patients with $\mathrm{CD}$, menarche occurred at the age of 16 years or later in $73 \%$ of female patients in whom disease onset preceded puberty. In a few patients, menarche was delayed until the early 20's (23). In another study (24), the onset of puberty was taken as breast stage 2 in girls and testicular volume of $4 \mathrm{ml}$ in boys. By these criteria, the mean age of onset of puberty was 12.6 years in young female patients with IBD compared with 11.1 years in healthy controls. In boys, the onset of puberty was 13.2 years in patients with IBD and 12.4 years in healthy controls (24). Furthermore, the duration of puberty may also be prolonged, particularly in patients with frequent disease relapses during this period (24).

Studies that have analysed the long-term growth of IBD patients from adolescence into adulthood have observed persistent stunting into adulthood at an incidence of $15-30 \%$ (25-27). A recent study of adult height in CD patients with pre-pubertal onset of symptoms showed that in the majority of patients $(85 \%)$ the final height was less than 'target height', and in $22 \%$ the final height deficit was $>10 \mathrm{~cm} \mathrm{(28).}$

Children suffering from JIA and IBD who show severe growth retardation may have normal pulsatile growth hormone $(\mathrm{GH})$ secretion, but have reduced IGF-1 (insulinlike growth factor-1) levels suggestive of GH resistance (29). Two randomised controlled trials assessing the efficacy of recombinant human growth hormone $(\mathrm{rhGH})$ in JIA have shown favourable results up to 4 years of treatment $(30,31)$. A randomised placebo-controlled double blind cross over study using $\mathrm{rhGH}$ at $0.033 \mathrm{mg} / \mathrm{kg} / \mathrm{day}$ showed significant improvement in height velocity and height SDS during treatment (30). A randomised controlled study using a moderately high $\mathrm{rhGH}$ dose of $0.05 \mathrm{mg} / \mathrm{kg} /$ day showed that rhGH was effective in significantly improving height velocity SDS over a 4-year treatment period, and prevented the further deterioration in height SDS seen in those patients not treated with rhGH (31).

Only one prospective study has evaluated the response of rhGH in IBD patients (nine CD, one indeterminate colitis) with a history of chronic glucocortico-steroid exposure (32). rhGH administration at $0.05 \mathrm{mg} / \mathrm{kg} /$ day was associated with improved growth at 1 year from baseline and compared to controls. Improvement of height velocity from a mean of $3.5 \mathrm{~cm} /$ year at baseline to a mean of $7.7 \mathrm{~cm} /$ year was observed after 6 months of treatment. There was also a concomitant improvement of serum levels of IGF-1 and IGFBP-3 after treatment. This improvement was independent of disease activity and steroid dose (32). Preliminary results from a recent randomised controlled trial of $\mathrm{GH}$ in children with IBD showed improved growth in the rhGH-treated group at 1 year from baseline (33). However, pilot results from another randomised trial of $\mathrm{rhGH}$ at $0.05 \mathrm{mg} / \mathrm{kg} /$ day for children with CD (3 patients) versus placebo treatment (4 patients) showed no improvement in growth for the pooled result of growth for all 7 patients during rhGH treatment. The 4 patients treated with placebo were subsequently treated with rhGH (34).

Overall, these studies suggest that moderately high doses of rhGH can improve short-term height velocity, prevent further deterioration of linear growth and reverse the catabolic state induced by the inflammatory process and chronic steroid use.

A direct association between factors produced during chronic inflammation and growth failure has been proposed $(29,35,36)$. In patients with systemic JIA, inhibition of linear growth is observed during disease activity periods, with subsequent growth rate normalisation during remission $(35,36)$. In children with systemic JIA and growth retardation, growth velocity during GH treatment is inversely correlated with inflammation intensity (29). Pro-inflammatory cytokines may be associated with the growth failure observed in JIA and IBD by acting through both systemic effects and/or locally at the level of the growth plate.

\section{Systemic and local control of bone growth}

Articular chondrocytes produce and maintain an extracellular matrix (ECM) that is able to assist joint articulation and resist physical deformation. Growth plate cartilage is progressively synthesised at the epiphyseal growth plate and subsequently replaced by bone, with accompanying longitudinal bone growth (37).

The growth plate is a thin cartilage layer located near the ends of vertebrae and long bones (38). It consists of both chondrocytes and their ECM, where proteoglycans and collagen type II predominate. A feature of endochondral bone growth is the exact chronological and spatial organisation of chondrocytes in the growth plate. The chondrocytes differentiate through a sequence of maturational phases whilst staying in a fixed location (39) (Fig. 1).

Undifferentiated progenitors within the reserve stem cell zone differentiate into chondrocytes and advance through a proliferative phase. Immediately after the termination of cell division, the cells undergo terminal differentiation into hypertrophic chondrocytes (40). These chondrocytes are considerably larger, with increases in Golgi apparatus and rough endoplasmic reticulum, reflecting greater ECM synthesis (41). The rate of endochondral bone growth attributed to a specific growth plate in any given period of time results from a complex synchronisation of proliferative kinetics, ECM production, and hypertrophic chondrocyte enlargement (42). The exact control of these processes is yet to be elucidated, and any alteration of these variables by external factors such as pro-inflammatory cytokines may induce growth modulatory effects. 


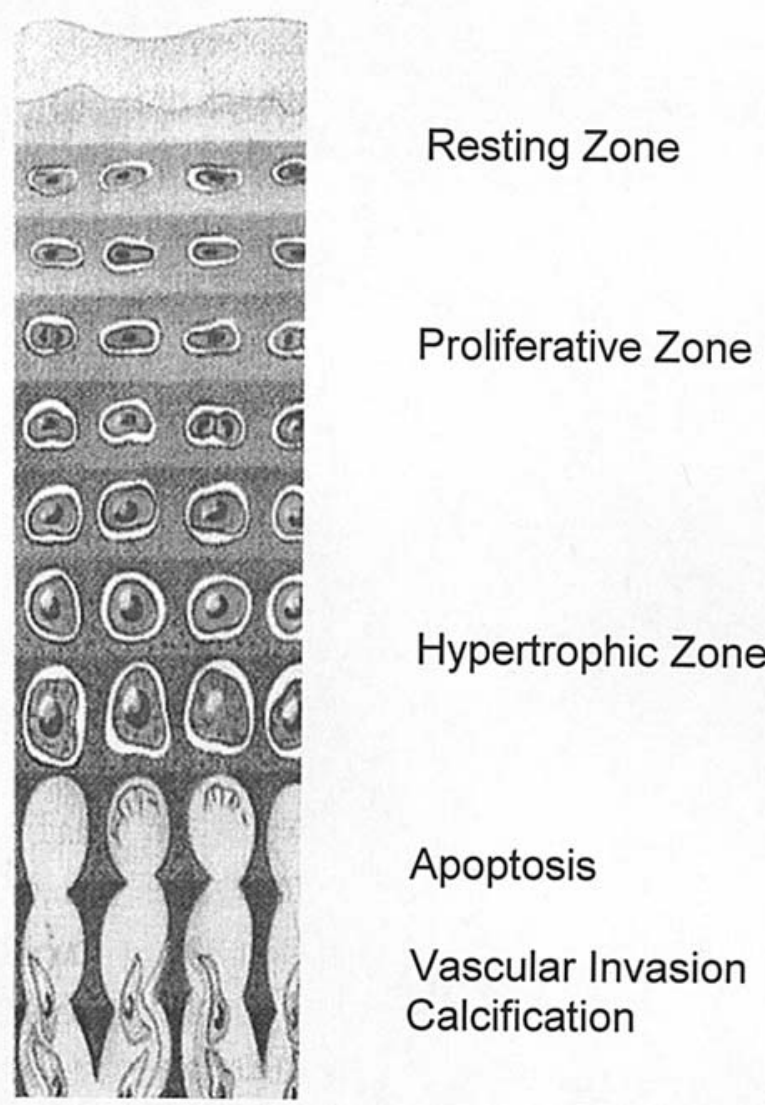

Figure 1. Chondrocyte maturational phases within the growth plate.

The growth plate chondrocytes are in columns in the direction of the bone's longitudinal axis. Longitudinal and transverse septae consisting of ECM divide each column and each chondrocyte inside the columns respectively. The ECM of the growth plate determines its mechanical properties. The ECM also offers a scaffold for chondrocyte adhesion and movement, thereby contributing to the growth plate's histological design (43). During terminal differentiation, mineralisation of the ECM surrounding the hypertrophic chondrocytes occurs. Functionally the ECM changes to an environment permitting vascular invasion, allowing osteoclasts and differentiating osteoblasts to remodel the new cartilage into bone tissue (44).

In order to compensate for the rapid chondrocyte proliferation and hypertrophy rates, the differentiated chondrocyte must be removed in order to maintain a constant growth plate width. In growing rats, it has been determined that eight hypertrophic chondrocytes are removed each day by apoptosis (39). However, the growth plate tapers and ultimately disappears near the end of the growth phase. The control of growth termination is central to the growth plate, with the cessation of growth preceeding rather than following growth plate fusion $(45,46)$.

GH and IGF-1 are two of the most significant and widely investigated regulators of post-natal bone growth, and exert direct effects on the growth plate. A dual effector theory of GH/IGF-1 action at the level of the growth plate has been proposed, whereby $\mathrm{GH}$ acts directly on germinal zone precursors of the growth plate to induce chondrocyte differentiation, with a subsequent increase in local IGF-1 synthesis, which in turn results in the clonal enlargement of chondrocyte columns in an autocrine/paracrine mechanism $(47,48)$. However, chondrocytes in all of the growth plate's maturational zones express IGF-1, with IGF-1 mRNA expression predominantly limited to the hypertrophic zone. In vivo studies involving IGF-1 infusion of hypophysectomised rats, show stimulation of chondrocytes in all maturational zones, including the hypertrophic (49-51). Growth plate-derived IGF-1 is considerably more important for post-natal growth compared to serum IGF-1 $(52,53)$.

Parathyroid hormone-related peptide (PTHrP) plays an important role in locally controlling the cellular function of growth plate chondrocytes. Mice missing the PTH/PTHrP receptor gene, and mice that are homozygous for the ablation of the PTHrP gene have comparable growth plate morphologies (54). Accelerated chondrocyte differentiation and early mineralisation produce the thin growth plate observed in these mice. Conversely, mice overexpressing the PTHrP gene show a remarkable deceleration of chondrocyte differentiation and a larger growth plate (55). PTHrP, together with the morphogen Indian hedgehog (Ihh), exert important effects on bone growth (38).

Sex steroids induce direct effects on the growth plate, and are extremely important in the control of endochondral growth. Androgen receptor, estrogen receptor $\alpha(E R \alpha)$ and estrogen receptor $\beta(E R \beta)$ mRNA and protein expression have been observed in growth plate tissue (56). This demonstrates that androgens and estrogens directly control growth plate cellular function. The growth plate also has the capacity for steroidogenesis and aromatisation (57). However, it has been difficult to determine whether androgens directly influence the growth plate cartilage. Nonaromatisable androgens, such as dihydrotestosterone, control both chondrocyte proliferation and differentiation, by inducing local IGF-1 synthesis and increasing IGF-1 receptor expression $(58,59)$. In both sexes, estrogen is the essential hormone in regulating growth plate acceleration and fusion $(60,61)$. Estrogen changes proliferation, alkaline phosphatase activity and proteoglycan synthesis in chondrocytes $(62,63)$. Interestingly, growth plate chondrocyte proliferation is increased by low levels of estrogen and reduced by high levels (64).

Pro-inflammatory cytokines are involved in bone development, in the initiation and control of skeletal tissue growth, and in regulating bone remodelling (65). Both TNF and IL-1ß may act at the level of the growth plate. TNF $\alpha$ induces neo-vascularisation in vivo, and may be involved in the stimulation of growth plate vascular invasion (66). IL-1ß mRNA has been localised in the calcified cartilage zone of the growth plate, and together with bone morphogenetic protein (BMP) enhances cartilage formation in vitro (67). However, whilst cytokines play important roles in bone development, the elevated concentrations of proinflammatory cytokines associated with JIA and IBD may lead to detrimental effects on bone growth through systemic effects and/or a local effect at the level of the growth plate.

\section{Systemic effects of cytokines through the GH/IGF axis}

Elevated levels of circulating IL-6 have been observed in children suffering from JIA and IBD $(68,69)$. These patients 


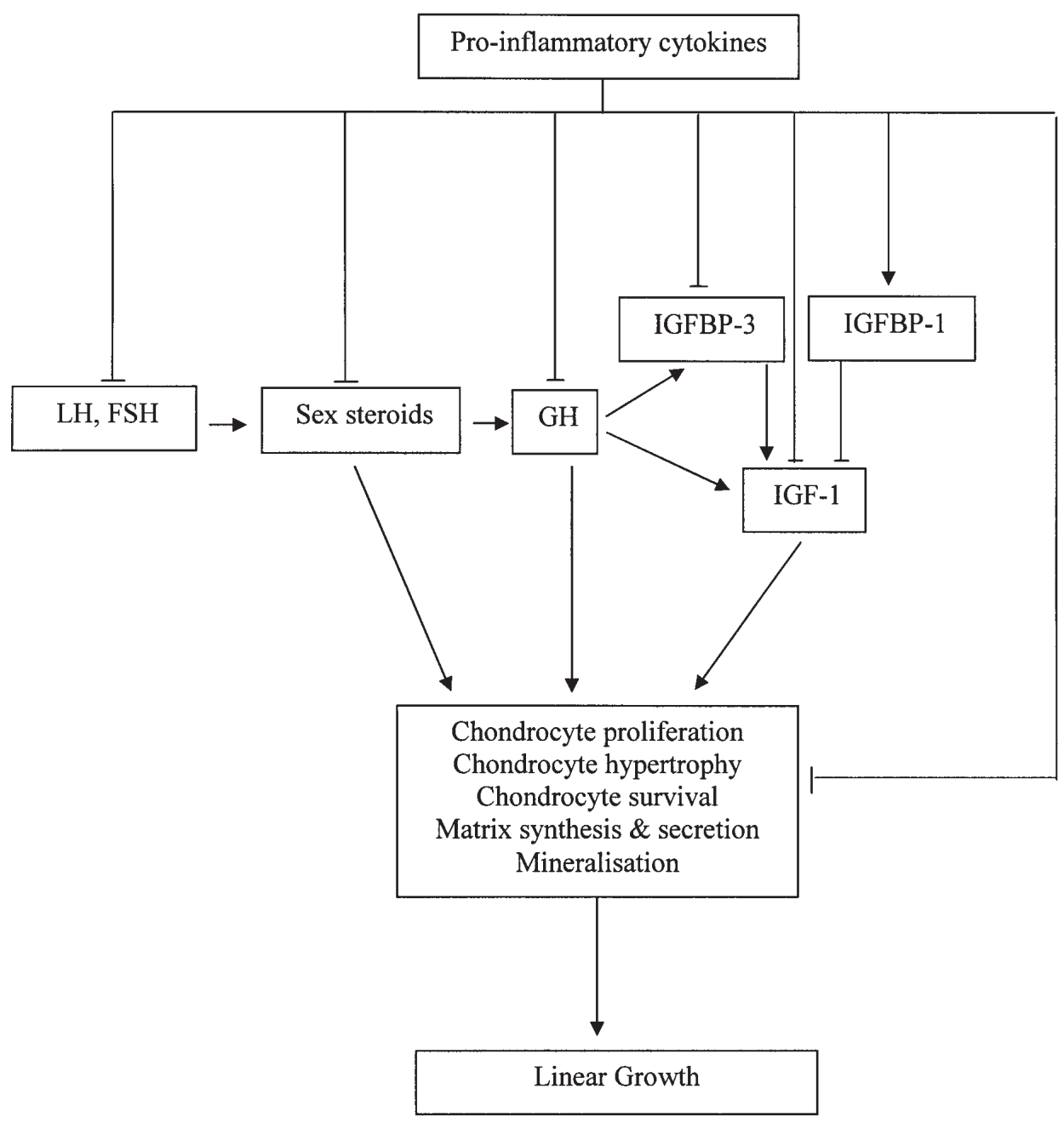

Figure 2. Possible mechanisms underlying pro-inflammatory cytokine-mediated growth retardation at a systemic and local level.

show reduced circulating IGF-1 levels, with unchanged GH levels $(70,71)$. Low concentrations of IGF binding protein-3 (IGFBP-3) may also be seen in these patients (70-72). The mechanisms by which the pro-inflammatory cytokine IL-6 causes systemic effects on growth have been examined using the NSE/hIL-6 transgenic murine model, which overexpresses IL-6. Elevated circulating IL-6 and growth retardation are observed in these mice (73), however growth is normalised following IL-6 neutralisation (74). Like the JIA and IBD patients, these transgenic mice have reduced circulating IGF-1 levels, with unchanged GH (73), and also reduced IGFBP-3 levels (72). It is probable that IL-6 reduces IGF-1 levels by increased clearance. This is because the association of IGF-1 in the circulating ternary complex with IGFBP-3 and an acidlabile subunit (ALS) markedly prolongs the half-life of IGF-1 (72).

The pro-inflammatory cytokine $\mathrm{TNF} \alpha$ is also associated with JIA and IBD (7,75). TNF-transgenic mice, which overexpress $\mathrm{TNF} \alpha$, show growth retardation $(76,77)$. However, alterations in the IGF-1/GH axis have yet to be examined in this transgenic model.

IL-1ß treatment reduces plasma levels of both IGF-1 and ALS (78-80). Hepatic IGFBP-1 expression is increased in septic rats, which inhibits IGF-1 bioactivity, as phosphorylated IGFBP-1 has a higher affinity for IGF-1 than the
IGF-1 receptor $(81,82)$. This effect can be completely reversed by treatment with an IL-1 receptor antagonist (82). IL-1ß also increases IGFBP-1 protein and mRNA synthesis in the HepG2 hepatoma cell line (83-85).

\section{Local effects of cytokines on the growth plate through the GH/IGF axis}

The effect of IL-6, IL-1ß, and TNF $\alpha$ on chondrocytes has been comprehensively studied in vitro. However, investigations have predominantly focused on the effects of cytokines on articular chondrocytes, rather than on growth plate chondrocytes.

Localised damage to the growth plate of long bones is associated with inflammatory synovitis, indicated by increased concentrations of synovial IL- $6, \mathrm{TNF} \alpha$ and IL-1ß (86). This suggests that the cytokines in the synovial fluid can act directly on the growth plate from the adjacent synovial space.

The effect of IL-6 on articular chondrocyte differentiation has been described. It has been shown that the stimulatory effect of IGF-1 on proteoglycan synthesis is reduced by IL-6 (87). In bovine articular chondrocytes, IL-6 with the addition of soluble IL-6 receptor also inhibits the expression of gene markers of chondrocyte differentiation, including aggrecan, 
type II collagen and link proteins (88). IL-6 has been shown to have no effect on growth plate chondrocyte dynamics (89), however these experiments were performed without the addition of the soluble IL- 6 receptor.

Both IL-1ß and TNF $\alpha$ have been shown to inhibit growth plate chondrocyte differentiation (90-94). IL-1ß and TNF $\alpha$ have also been shown to increase DNA synthesis in growth plate and costal chondrocytes (95-97), which may be the mechanism for the excessive endochondral bone growth observed in the affected limbs of children with oligoarticular JIA. TNF $\alpha$ has been shown to cause apoptosis in chick chondrocyte cultures (98) and to inhibit cartilaginous nodule formation and the production of cartilage-specific proteoglycans in ATDC5 murine growth plate cells (99). TNFa has also been shown to inhibit proteoglycan production in foetal mouse metatarsals (100). This study also showed that IL-17 synergises with TNF $\alpha$ to further inhibit proteoglycan synthesis. IL-1B also synergises with TNF $\alpha$ to inhibit endochondral growth in foetal rat metatarsal bones (89).

The cellular mechanisms through which cytokines act on the growth plate have yet to be elucidated. Possible mechanisms include increased cell apoptosis induced by TNF $\alpha(89,99)$, the down-regulation of Sox 9 gene expression (101), a master regulatory factor for chondrocyte differentiation and cartilage formation (102), effects on the growth plate through the gonadal axis (105-107), inhibition of IGF-1 signalling (106-108) and interference with GH signalling (109).

The IGF-1 signalling pathway is a major autocrine/ paracrine controller of endochondral bone growth (110). IGF-1 exerts its cellular effects through a receptor tyrosine kinase (IGF-1R), which is expressed in growth plate chondrocytes. However, studies have shown that neither IL-1ß nor TNF $\alpha$ reduce IGF-1R expression (111), alter IGF-1R affinity (112) or inhibit the intrinsic tyrosine kinase activity of the IGF-1R $(113,114)$. It is therefore doubtful that inflammatory cytokines affect the IGF-1 signalling cascade at the IGF-1 receptor level.

IGF-1 receptor binding initiates an IGF-1 signalling cascade, which may be altered by pro-inflammatory cytokines at one or more points: insulin receptor substrate (IRS) phosphorylation; the Erk1/Erk2 mitogen-activated protein kinase (MAPK) signalling pathway; the phosphatidylinositol 3-kinase (PI-3K) signalling pathway and Akt phosphorylation. The effects of pro-inflammatory cytokines on IGF-1 signalling in growth plate chondrocytes at these junctures have yet to be determined. However, effects of cytokines on IGF-1 signalling have been investigated in a number of other cell types. TNF $\alpha$ and IL-1ß inhibit IRS-1 phosphorylation in both myoblasts $(106,114)$ and breast cancer epithelial cells (113). TNF $\alpha$ inhibits MAPK-kinase phosphorylation in neuronal cells (107), prevents the intranuclear translocation of PI-3K in osteoblasts (108) and inhibits Akt phosphorylation and activation in neuronal cells (107).

Increased concentrations of pro-inflammatory cytokines may also alter the effects of $\mathrm{GH}$ on the growth plate. Cytokines may interfere with GH receptor signalling (109), although little research has been performed in this area. IL-1ß and TNF $\alpha$ induce the expression of SOCS (suppressor of cytokine signalling proteins) (115). SOCS are cellular signalling proteins that down-regulate cytokine signalling and alter GH signalling $(116,117)$. Mice genetically modified to not express SOCS2 show gigantism accompanied by deregulated GH signalling (118). Furthermore, IL-6 may reduce liver GH signalling by inducing SOCS3 (119), a mechanism that may explain $\mathrm{GH}$ resistance observed in inflammatory diseases.

\section{Conclusions}

Pro-inflammatory cytokines may modulate growth patterns in children with inflammatory diseases such as Juvenile Idiopatic Arthritis and Inflammatory Bowel Disease through both systemic and local effects of the GH/IGF-1 axes (Fig. 2). By elucidating the fundamental cellular mechanisms that are altered in growth plate development, we will be in a better position to treat the abnormal growth patterns observed in affected children.

\section{Acknowledgements}

We are grateful to Novo Nordisk UK Ltd. and the Biotechnology and Biological Sciences Research Council (BBSRC) for their generous support.

\section{References}

1. Grom AA, Murray KJ, Luyrink L, Emery H, Passo MH, Glass DN, Bowlin T and Edwards C: Patterns of expression of tumor necrosis factor alpha, tumor necrosis factor beta, and their receptors in synovia of patients with juvenile rheumatoid arthritis and juvenile spondylarthropathy. Arthritis Rheum 39: 1703-1710, 1996

2. Yetgin S, Ozen S, Saatci U, Bakkaloglu A, Topaloglu R, Yenicesu I, Olcay L, Okur H, Karaagaoglu E, Tuncer M and Besbas N: Evaluation of tumour necrosis factor alpha, interferon gamma and granulocyte-macrophage colony stimulating factor levels in juvenile chronic arthritis. Rheumatology 38: 468-471, 1999.

3. Rooney M, Varsani H, Martin K, Lombard PR, Dayer JM and Woo P: Tumour necrosis factor alpha and its soluble receptors in juvenile chronic arthritis. Rheumatology 39: 432-438, 2000.

4. Almawi WY, Beyhum HN, Rahme AA and Rieder MJ: Regulation of cytokine and cytokine receptor expression by glucocorticoids. J Leukoc Biol 60: 563-572, 1996.

5. Corral LG, Muller GW, Moreira AL, Chen YX, Wu MD, Stirling D and Kaplan G: Selection of novel analogs of thalidomide with enhanced tumor necrosis factor alpha inhibitory activity. Mol Med 2: 506-515, 1996.

6. Kutukculer N, Caglayan S and Aydogdu F: Study of proinflammatory (TNF-alpha, IL-1 alpha, IL-6) and T-cell-derived (IL-2, IL-4) cytokines in plasma and synovial fluid of patients with juvenile chronic arthritis: Correlations with clinical and laboratory parameters. Clin Rheumatol 17: 288-292, 1998.

7. Wilkinson N, Jackson G and Gardner-Medwin J: Biologic therapies for juvenile arthritis. Arch Dis Child 88: 186-191, 2003.

8. Yilmaz M, Kendirli SG, Altintas D, Bingol G and Antmen B: Cytokine levels in serum of patients with juvenile rheumatoid arthritis. Clin Rheumatol 20: 30-35, 2001.

9. Grottrup-Wolfers E, Moeller J, Karbach U, Muller-Lissner S and Endres S: Elevated cell-associated levels of interleukin 1 beta and interleukin 6 in inflamed mucosa of inflammatory bowel disease. Eur J Clin Invest 26: 115-122, 1996.

10. Reimund JM, Wittersheim C, Dumont S, Muller CD, Kenney JS, Baumann R, Poindron P and Duclos B: Increased production of tumour necrosis factor-alpha interleukin-1 beta, and interleukin6 by morphologically normal intestinal biopsies from patients with Crohn's disease. Gut 39: 684-689, 1996.

11. Zak M, Müller J and Karup Pedersen F: Final height, armspan, subischial leg length and body proportions in juvenile chronic arthritis. Horm Res 52: 80-85, 1999. 
12. Simon D, Lucidarme N, Prieur A-M, Ruiz J-C and Czernichow P: Treatment of growth failure in Juvenile chronic arthritis. Horm Res 58: 28-32, 2002.

13. Ahmed SF, Tucker P, Mushtaq T, Wallace AM, Williams DM and Hughes IA: Short-term effects on linear growth and bone turn in children randomized to receive prednisolone or dexamethasone. Clin Endocrinol 57: 185-191, 2002.

14. Wang SJ, Yang YH, Lin YT, Yang CM and Chiang BL: Attained adult height in juvenile rheumatoid arthritis with or without corticosteroid treatment. Clin Rheumatol 21: 363-368, 2002.

15. Rusconi R, Corona F, Grassi A and Carnelli V: Age at menarche in juvenile rheumatoid arthritis. J Pediatr Endocrinol Metab 16 (suppl 2): 285-288, 2003.

16. Simon S, Whiffen J and Shapiro F: Leg-length discrepancies in monoarticular and pauciarticular juvenile rheumatoid-arthritis. $\mathrm{J}$ Bone Joint Surg Am 63: 209-215, 1981.

17. Sherry DD, Stein LD, Reed AM, Schanberg LE and Kredich DW: Prevention of leg length discrepancy in young children with pauciarticular juvenile rheumatoid arthritis by treatment with intraarticular steroids. Arthritis Rheum 42: 2330-2334, 1999.

18. Heuck C, Wolthers OD and Herlin T: Growth-suppressive effect of intra-articular glucocorticoids detected by knemometry. Horm Res 52: 95-96, 1999.

19. Cezard JP, Touati G, Alberti C, Hugot JP, Brinon C and Czernichow P: Growth in paediatric Crohn's disease. Horm Res 58 (suppl 1): 11-15, 2002.

20. Motil KJ, Grand RJ, Davis-Kraft L, Ferlic LL and Smith EO: Growth failure in children with inflammatory bowel disease: a prospective study. Gastroenterology 105: 681-691, 1993.

21. Carel JC: Can we increase adolescent growth? Eur J Endocrinol 151 (suppl 3): U101-U108, 2004.

22. Stephens M, Batres LA, Ng D and Baldassano R: Growth failure in the child with inflammatory bowel disease. Semin Gastrointest Dis 12: 253-262, 2001.

23. Ferguson A and Sedgwick DM: Juvenile onset inflammatory bowel disease: height and body mass index in adult life. BMJ 308: 1259-1263, 1994.

24. Brain CE and Savage MO: Growth and puberty in chronic inflammatory bowel disease. Baillieres Clin Gastroenterol 8: 83-100, 1994

25. Castile RG, Telander RL, Cooney DR, Ilstrup DM, Perrault J, van Heerden J and Stickler GB: Crohn's disease in children: assessment of the progression of disease, growth, and prognosis. J Pediatr Surg 15: 462-469, 1980

26. Puntis J, McNeish AS and Allan RN: Long term prognosis of Crohn's disease with onset in childhood and adolescence. Gut 25: 329-336, 1984.

27. Markowitz J, Grancher K, Rosa J, Aiges H and Daum F: Growth failure in pediatric inflammatory bowel disease. J Pediatr Gastroenterol Nutr 16: 373-380, 1993.

28. Sawczenko A, Ballinger AB, Croft NM, Sanderson IR and Savage MO: Adult height in patients with early onset of Crohn's disease. Gut 52: 454-455, 2003.

29. Davies UM, Rooney M, Preece MA, Ansell BM and Woo P: Treatment of growth-retardation in juvenile chronic arthritis with recombinant human growth-hormone. J Rheumatol 21: 153-158, 1994.

30. Saha MT, Haapasaari J, Hannula S, Sarna S and Lenko HL: Growth hormone is effective in the treatment of severe growth retardation in children with juvenile chronic arthritis. Double blind placebo-controlled follow up study. J Rheumatol 31: 1413-1417, 2004.

31. Bechtold S, Ripperger P, Hafner R, Said E and Schwarz HP: Growth hormone improves height in patients with juvenile idiopathic arthritis: 4-year data of a controlled study. J Pediatr 143: 512-519, 2003.

32. Mauras N, George D, Evans J, Milov D, Abrams S, Rini A, Welch S and Haymond MW: Growth hormone has anabolic effects in glucocorticosteroid-dependent children with inflammatory bowel disease: a pilot study. Metabolism 51: 127-135, 2002.

33. van Beek R, van der Skuis I, Bouquet J and Muinck Keizer-Shrama S: First year results of additional treatment with recombinant human growth hormone for growth retardation and osteopenia in children with inflammatory bowel disease. Horm Res 58 (suppl 2): 55-56, 2002.

34. Calenda KA, Schornagel IL, Sadeghi-Nejad A and Grand RJ: Effect of recombinant growth hormone treatment on children with Crohn's disease and short stature: A pilot study. Inflamm Bowel Dis 11: 435-441, 2005.
35. Kuhns JG and Swaim LT: Disturbances in growth in chronic arthritis in children. Am J Dis Child 43: 1180-1183, 1932.

36. Ansell BM and Bywaters FGL: Growth in Still's disease. Ann Rheum Dis 15: 295-319, 1956.

37. Farquarson C: Bone growth. In: Biology of Growth of Domestic Animals. Scanes CG (ed). Iowa State Press, Iowa, pp170-185, 2003.

38. Kronenberg HM: Developmental regulation of the growth plate. Nature 423: 332-336, 2003.

39. Hunziker EB, Schenk RK and Cruzorive LM: Quantitation of chondrocyte performance in growth-plate cartilage during longitudinal bone-growth. J Bone Joint Surg Am 69A: 162-173, 1987.

40. Breur GJ, Turgai J, Vanenkevort BA, Farnum CE and Wilsman NJ: Stereological and serial section analysis of chondrocytic enlargement in the proximal tibial growth-plate of the rat. Anat Rec 239: 255-268, 1994.

41. Buckwalter JA, Mower D, Ungar R, Schaeffer J and Ginsberg B: Morphometric analysis of chondrocyte hypertrophy. J Bone Joint Surg Am 68A: 243-255, 1986.

42. Breur GJ, Vanenkevort BA, Farnum CE and Wilsman NJ: Linear relationship between the volume of hypertrophic chondrocytes and the rate of longitudinal bone-growth growth plates. J Orthop Res 9: 348-359, 1991.

43. Bateman JF, Lamandé SR and Ramshaw JAM: Collagen superfamily. In: Extracellular Matrix. Comper WD (ed). Vol 2. Harwood Academic Publishers, Amsterdam, pp22-67, 1996.

44. Gerber HP, Vu TH, Ryan AM, Kowalski J, Werb Z and Ferrara N: VEGF couples hypertrophic cartilage remodeling, ossification and angiogenesis during endochondral bone formation. Nat Med 5: 623-628, 1999.

45. Parfitt AM: Misconceptions (1). Epiphyseal fusion causes cessation of growth. Bone 30: 337-339, 2002.

46. Nilsson $\mathrm{O}$ and Baron J: Fundamental limits on longitudinal bone growth: growth plate senescence and epiphyseal fusion. Trends Endocrin Metab 15: 370-374, 2004

47. Zezulak KM and Green H: The generation of insulin-like growth factor-1-sensitive cells by growth-hormone action. Science 233: 551-553, 1986.

48. Isaksson OGP, Jansson JO and Gause IAM: Growth-hormone stimulates longitudinal bone-growth directly. Science 216: 1237-1239, 1982.

49. Hunziker EB, Wagner J and Zapf J: Differential effects of insulinlike growth factor I and growth hormone on developmental stages of rat growth plate chondrocytes in vivo. J Clin Invest 93: 1078-1086, 1994.

50. Reinecke M, Schmid AC, Heyberger-Meyer B, Hunziker EB and Zapf J: Effect of growth hormone and insulin-like growth factor I (IGF-I) on the expression of IGF-I messenger ribonucleic acid and peptide in rat tibial growth plate and articular chondrocytes in vivo. Endocrinology 141: 2847-2853, 2000.

51. Smink JJ, Koster JG, Gresnigt MG, Rooman R, Koedam JA and Van Buul-Offers SC: IGF and IGF-binding protein expression in the growth plate of normal, Dexamethasone-treated and human IGF-II transgenic mice. J Endocrinol 175: 143-153, 2002.

52. Yakar S, Liu JL, Stannard B, Butler A, Accili D, Sauer B and LeRoith D: Normal growth and development in the absence of hepatic insulin-like growth factor I. Proc Natl Acad Sci USA 96: 7324-7329, 1999.

53. Yakar S, Rosen CJ, Beamer WG, Ackert-Bicknell CL, Wu Y, Liu JL, Ooi GT, Setser J, Frystyk J, Boisclair YR and LeRoith D: Circulating levels of IGF-1 directly regulate bone growth and density. J Clin Invest 110: 771-781, 2002.

54. Lanske B, Karaplis AC, Lee K, Luz A, Vortkamp A, Pirro A, Karperien M, Defize LHK, Ho C, Mulligan RC, AbouSamra AB, Juppner H, Segre GV and Kronenberg HM: PTH/PTHrP receptor in early development and Indian hedgehog-regulated bone growth. Science 273: 663-636, 1996.

55. Weir EC, Philbrick WM, Amling M, Neff LA, Baron R and Broadus AE: Targeted overexpression of parathyroid hormonerelated peptide in chondrocytes causes chondrodysplasia and delayed endochondral bone formation. Proc Natl Acad Sci USA 93: 10240-10245, 1996.

56. Vanderschueren D, Vandenput L, Boonen S, Lindberg MK, Bouillon R and Ohlsson C: Androgens and bone. Endocr Rev 25: 389-425, 2004.

57. van der Eerden BCJ, Lowik CWGM, Wit JM and Karperien M: Expression of estrogen receptors and enzymes involved in sex steroid metabolism in the rat tibia during sexual maturation. J Endocrinol 180: 457-467, 2004. 
58. Blanchard O, Tsagris L, Rappaport R, Duval-Beaupere G and Corvol M: Age-dependent responsiveness of rabbit and human cartilage cells to sex steroids in vitro. J Steroid Biochem Mol Biol 40: 711-716, 1991.

59. Krohn K, Haffner D, Hugel U, Himmele R, Klaus G, Mehls O and Schaefer F: 1,25(OH)2D3 and dihydrotestosterone interact to regulate proliferation and differentiation of epiphyseal chondrocytes. Calcif Tissue Int 73: 400-410, 2003.

60. Carani C, Qin K, Simoni M, Faustini M, Serpente S, Boyd J, Korach KS and Simpson ER: Effect of testosterone and estradiol in a man with aromatase deficiency. New Eng J Med 337: 91-95, 1997

61. Morishima A, Grumbach MM, Simpson ER, Fisher C and Qin K: Aromatase deficiency in male and female siblings caused by a novel mutation and the physiological role of estrogens. J Clin Endocrinol Metab 80: 3689-3698, 1995.

62. Nasatzky E, Schwartz Z, Boyan BD, Soskolne WA and Ornoy A: Sex-dependent effects of 17-beta-estradiol on chondrocyte differentiation in culture. J Cell Physiol 154: 359-367, 1993.

63. Schwartz Z, Nasatzky E, Ornoy A, Brooks BP, Soskolne WA and Boyan BD: Gender-specific, maturation-dependent effects of testosterone on chondrocytes in culture. Endocrinology 134: 1640-1647, 1994

64. Frank GR: Role of estrogen and androgen in pubertal skeletal physiology. Med Pediatr Oncol 41: 217-221, 2003.

65. Goldring MB and Goldring SR: Skeletal tissue response to cytokines. Clin Orthop Relat Res 258: 245-278, 1990.

66. Folkman J and Klagsbrun M: Vascular physiology. A family of angiogenic peptides. Nature 329: 671-672, 1987.

67. Mahy PR and Urist MR: Experimental heterotopic bone formation induced by bone morphogenetic protein and recombinant human interleukin-1B. Clin Orthop Relat Res 237: 236-244, 1988.

68. Sylvester FA, Wyzga N, Hyams JS and Gronowicz GA: Effect of Crohn's disease on bone metabolism in vitro: a role for interleukin-6. J Bone Miner Res 17: 695-702, 2002.

69. Ou LS, See LC, Wu CJ, Kao CC, Lin YL and Huang JL: Association between serum inflammatory cytokines and disease activity in juvenile idiopathic arthritis. Clin Rhuematol 21: 52-56, 2002.

70. De Benedetti F, Meazza C, Oliveri M, Pignatti P, Vivarelli M, Alonzi T, Fattori E, Garrone S, Barreca A and Martini A: Effect of IL- 6 on IGF binding protein-3: A study in IL- 6 transgenic mice and in patients with systemic juvenile idiopathic arthritis. Endocrinology 142: 4818-4826, 2001.

71. Davies UM, Jones J, Reeve J, Camacho Hubner C, Charlett A, Ansell BM, Preece MA and Woo PMM: Juvenile rheumatoid arthritis - Effects of disease activity and recombinant human growth hormone on insulin-like growth factor 1, insulin-like growth factor binding proteins 1 and 3 , and osteocalcin. Arthritis Rheum 40: 332-340, 1997.

72. Tsatsoulis A, Siamopoulou A, Petsoukis C, Challa A, Bairaktari E and Seferiadis K: Study of growth hormone secretion and action in growth-retarded children with juvenile chronic arthritis (JCA). Growth Horm IGF Res 9: 143-149, 1999.

73. DeBenedetti F, Alonzi T, Moretta A, Lazzaro D, Costa P, Poli V, Martini A, Ciliberto $G$ and Fattori E: Interleukin 6 causes growth impairment in transgenic mice through a decrease in insulin-like growth factor-I-A model for stunted growth in children with chronic inflammation. J Clin Invest 99: 643-650, 1997.

74. De Benedetti F, Pignatti P, Vivarelli M, Meazza C, Ciliberto G, Savino R and Martini A: In vivo neutralization of human IL-6 (hIL-6) achieved by immunization of hIL-6-transgenic mice with a hIL-6 receptor antagonist. J Immunol 166: 4334-4340, 2001 .

75. Ardizzone S and Bianchi Porro G: Biologic therapy for inflammatory bowel disease. Drugs 65: 2253-2286, 2005.

76. Li P and Schwarz EM: The TNF-alpha transgenic mouse model of inflammatory arthritis. Springer Semin Immunopathol 25: 19-33, 2003.

77. Siegel SA, Shealy DJ, Nakada MT, Le JM, Wolfe DS, Probert L, Kollias G, Ghrayeb J, Vilcek J and Daddona PE: The mousehuman chimeric monoclonal-antibody ca2 neutralizes tnf in-vitro and protects transgenic mice from cachexia and TNF lethality in-vivo. Cytokine 7: 15-25, 1995.

78. Fan J, Char D, Bagby GJ, Gelato MC and Lang CH: Regulation of insulin-like growth factor-1 (IGF-1) and IGF-binding proteins by tumour necrosis factor. Am J Physiol 269: 1204-1212, 1995.
79. Barreca A, Ketelslegers JM, Arvigo M, Minuto F and Thissen JP: Decreased acid-labile subunit (ALS) levels by endotoxin in vivo and by interleukin-1 beta in vitro. Growth Horm IGF Res 8: 217-223, 1998.

80. Delhanty PJD: Interleukin-1 beta suppresses growth hormoneinduced acid-labile subunit mRNA levels and secretion in primary hepatocytes. Biochem Biophys Res Commun 243: 269-272, 1998.

81. Jones JI, Dercole AJ, Camachohubner C and Clemmons DR: Phosphorylation of insulin-like growth-factor (IGF)-binding protein-1 in cell-culture and in vivo - effects on affinity for IGF1. Proc Natl Acad Sci USA 88: 7481-7485, 1991.

82. Lang CH, Fan J, Cooney R and Vary TC: IL-1 receptor antagonist attenuates sepsis-induced alterations in the IGF system and protein synthesis. Am J Physiol-Endoc M270: E430-E437, 1996

83. Samstein B, Hoimes ML, Fan J, Frost RA, Gelato MC and Lang CH: IL-6 stimulation of insulin-like growth factor binding protein (IGFBP)-1 production. Biochem Biophys Res Commun 228: 611-615, 1996.

84. Lang CH, Nystrom GJ and Frost RA: Regulation of IGF binding protein-1 in Hep G2 cells by cytokines and reactive oxygen species. Am J Physiol-Gastr L 276: G719-G727, 1999.

85. Frost RA, Nystrom GJ and Lang CH: Stimulation of insulin-like growth factor finding protein-1 synthesis by interleukin-1 beta: Requirement of the mitogen-activated protein kinase pathway. Endocrinology 141: 3156-3164, 2000.

86. de Hooge ASK, van de Loo FAJ, Bennink MB, Arntz OJ, Fiselier TJW, Franssen MJAM, Joosten LAB, van Lent PLEM, Richards CD and van den Berg WB: Growth plate damage, a feature of juvenile idiopathic arthritis, can be induced by adenoviral gene transfer of oncostatin M - A comparative study in gene-deficient mice. Arthritis Rheum 48: 1750-1761, 2003.

87. Lazarus DD, Moldawer LL and Lowry SF: Insulin-like growth factor-1 activity is inhibited by interleukin-1 alpha, tumor necrosis factor-alpha and interleukin-6. Lymphokine Cytokine Res 2: 2191-2223, 1993.

88. Legendre F, Dudhia J, Pujol JP and Bogdanowicz P: JAK/STAT but not ERK1/ERK2 pathway mediates interleukin (IL)-6/ soluble IL-6R down-regulation of Type II collagen, aggrecan core, and link protein transcription in articular chondrocytes. Association with a down-regulation of SOX9 expression. J Biol Chem 27: 2903-2912, 2003.

89. Martensson K, Chrysis D and Savendahl L: Interleukin-1 beta and TNF-alpha act in synergy to inhibit longitudinal growth in fetal rat metatarsal bones. J Bone Miner Res 19: 1805-1812, 2004

90. Goldring MB, Birkhead J, Sandell LJ, Kimura T and Krane SM: Interleukin-1 suppresses expression of cartilage-specific type-II and type-IX collagens and increases type-I and type-III collagens in human chondrocytes. J Clin Invest 82: 2026-2037, 1988.

91. Lefebvre V, Peetersjoris C and Vaes G: Modulation by interleukin-1 and tumor necrosis factor-alpha of production of collagenase, tissue inhibitor of metalloproteinases and collagen types in differentiated and dedifferentiated articular chondrocytes. Biochim Biophys Acta 1052: 366-378, 1990.

92. Lum ZP, Hakala BE, Mort JS and Recklies AD: Modulation of the catabolic effects of interleukin-1 beta on human articular chondrocytes by transforming growth factor-beta. J Cell Physiol 166: 351-359, 1996

93. Bolton MC, Dudhia J and Bayliss MT: Quantification of aggrecan and link-protein mRNA in human articular cartilage of different ages by competitive reverse transcriptase-PCR. Biochem J 319: 489-498, 1996.

94. Kato Y, Nakashima K, Iwamoto M, Murakami H, Hiranuma H, Koike T, Suzuki F, Fuchihata H, Ikehara Y, Noshiro M and Jikko A: Effects of interleukin-1 on syntheses of alkalinephosphatase, type-x collagen, and 1,25-dihydroxyvitamin-d(3) receptor, and matrix calcification in rabbit chondrocyte cultures. J Clin Invest 92: 2323-2330, 1993.

95. Soder O and Madsen K: Stimulation of chondrocyte DNAsynthesis by interleukin-1. Br J Rheumatol 27: 21-26, 1988.

96. Ikebe T, Hirata $M$ and Koga T: Effects of human recombinant tumor necrosis factor-alpha and interleukin-1 on the synthesis of glycosaminoglycan and DNA in cultured rat costal chondrocytes. J Immunol 140: 827-831, 1988.

97. Enomoto M, Pan HO, Kinoshita A, Yutani Y, Suzuki F and Takigawa M: Effects of tumor necrosis factor-alpha on proliferation and expression of differentiated phenotypes in rabbit costal chondrocytes in culture. Calcif Tissue Int 47: 145-151, 1990. 
98. Aizawa T, Kon T, Einhorn TA and Gerstenfeld LC: Induction of apoptosis in chondrocytes by tumor necrosis factor-alpha. J Orthop Res 19: 785-796, 2001.

99. Horiguchi M, Akiyama H, Ito H, Shigeno $\mathrm{C}$ and Nakamura T: Tumour necrosis factor-alpha up-regulates the expression of BMP-4 mRNA but inhibits chondrogenesis in mouse clonal chondrogenic EC cells, ATDC5. Cytokine 12: 5296-5301, 2000.

100.van Bezooijen RL, van der Wee-Pals L, Papapoulos SE and Lowik CWGM: Interleukin 17 synergises with tumour necrosis factor alpha to induce cartilage destruction in vitro. Ann Rheum Dis 61: 870-876, 2002.

101. Murakami S, Lefebvre V and de Crombrugghe B: Potent inhibition of the master chondrogenic factor Sox 9 gene by interleukin- 1 and tumor necrosis factor-alpha. J Biol Chem 275: 3687-3692, 2000.

102. Bi W, Deng JM, Zhang Z, Behringer RR and de Crombrugghe B: Sox 9 is required for cartilage formation. Nat Genet 22: 85-89, 1999.

103. Hales DB, Diemer T and Hales KH: Role of cytokines in testicular function. Endocrine 10: 201-217, 1999.

104. Terranova PF and Rice VM: Review: cytokine involvement in ovarian processes. Am J Reprod Immunol 37: 50-63, 1997.

105. Taranta A, Brama M, Teti A, De luca V, Scandurra R, Spera G, Agnusdei D, Termine JD and Migliaccio S: The selective estrogen receptor modulator raloxifene regulates osteoclast and osteoblast activity in vitro. Bone 30: 368-376, 2002.

106. Broussard SR, McCusker RH, Novakofski JE, Strle K, Shen WH, Johnson RW, Dantzer R and Kelley KW: IL-1 beta impairs insulin-like growth factor I-induced differentiation and downstream activation signals of the insulin-like growth factor I receptor in myoblasts. J Immunol 172: 7713-7720, 2004.

107. Kenchappa P, Yadav A, Singh G, Nandana S and Banerjee K: Rescue of TNFalpha-inhibited neuronal cells by IGF-1 involves Akt and c-Jun N-terminal kinases. J Neurosci 76: 466-474, 2004.

108. Martelli AM, Borgatti P, Bortul R, Manfredini M, Massari L, Capitani S and Neri LM: Phosphatidylinositol 3-kinase translocates to the nucleus of osteoblast-like MC3T3-E1 cells in response to insulin-like growth factor I and platelet-derived growth factor but not to the proapoptotic cytokine tumor necrosis factor alpha. J Bone Miner Res 15: 1716-1730, 2000. 109.von Laue S and Ross RJM: Inflammatory cytokines and acquired growth hormone resistance. Growth Horm IGF Res 10 (suppl B): 9-14, 2000.

110. Loveridge N, Farquharson $\mathrm{C}$ and Scheven BAA: Endogenous mediators of growth. Proc Nutr Soc 49: 443-450, 1990.

111. Blount $\mathrm{S}$ and Crawford A: Regulation of igf-1 receptors on rabbit articular chondrocytes by inflammatory mediators. Agents Actions Suppl 41: C177-C179, 1994

112. Matsumoto T, Tsukazaki T, Enomoto H, Iwasaki I and Yamashita S: Effects of interleukin-1-beta on insulin-like growth factor-1 autocrine/paracrine axis in cultured rat articular chondrocytes. Ann Rheum Dis 53: 128-133, 1994.

113. Shen WH, Zhou JH, Broussard SR, Freund GG, Dantzer R and Kelley KW: Proinflammatory cytokines block growth of breast cancer cells by impairing signals from a growth factor receptor. Cancer Res 62: 4746-4756, 2002.

114. Strle K, Broussard SR, McCusker RH, Shen WH, Johnson RW, Freund GG, Dantzer R and Kelley KW: Proinflammatory cytokine impairment of insulin-like growth factor I-induced protein synthesis in skeletal muscle myoblasts requires ceramide. Endocrinology 145: 4592-4602, 2004.

115. Shi H, Tzameli I, Bjorbaek C and Flier JS: Suppressor of cytokine signaling 3 is a physiological regulator of adipocyte insulin signalling. J Biol Chem 279: 34733-34740, 2004.

116. Krebs DL and Hilton DJ: SOCS proteins: Negative regulators of cytokine signalling. Stem Cells 19: 378-387, 2001.

117. Turnley AM: Role of SOCS2 in growth hormone actions. Trends Endocrin Metab 16: 53-58, 2005.

118. Horvat S and Medrano JF: Lack of Socs2 expression causes the high-growth phenotype in mice. Genomics 72: 209-212, 2001.

119. Denson LA, Held MA, Menon RK, Frank SJ, Parlow AF and Arnold DL: Interleukin-6 inhibits hepatic growth hormone signaling via upregulation of Cis and Socs-3. Am J PhysiolGastr L 284: G646-G654, 2003. 